Bolm Inst. oceanogr., S Paulo, 26:181-199, 1977

\title{
ASPECTS OF THE BREEDING BIOLOGY OF JANAIRA GRACILIS MOREIRA \& PIRES (CRUSTACEA, ISOPODA, ASELLOTA)
}

\author{
PLINIO SOARES MOREIRA \& ANA MARIA SETUBAL PIRES*
}

Instituto Oceanográfico da Universidade de são Paulo

\section{SYNOPSIS}

The biological aspects of incubating females of Janaira gracilis Moreira \& Pires, are described. The marsupium is formed by 4 pairs of oostegites arising from pereopods I-IV. The oostegites appear for the first time at the post-marsupial stage 7 (preparatory stage 1), growing successively at each moult until stage 9 (brooding stage 1), when they reach fully development. The sizes of the eggs increase with the body size of the females. The number of eggs, per female, is a linear function of the body volume, i.e., the fecundity increases with the female's body size. The number of eggs, embryos and juveniles decrease during the marsupial development. This decrease in brood number is higher between the last two marsupial stages, i.e., from stage C to $D$, than between the preceding marsupial stages. The average and overall brood mortality rate is of $38.95 \%$.

\section{NTRODUCT ION}

The development of the isopods is processed through a variable number of stages. The first stages of development is carried on inside the female brood pouch or marsupium. This period is called incubatory or marsupial period, and lasts from the newly deposited eggs to the release of juveniles

* Supported by a fellowship given by the Fundação de Amparo à Pesquisa do Estado de São Paulo (FAPESP).

PUBL. NO 391 DO INST. OCEAN. DA USP. 
into the habitat. The ultimate marsupial stage corresponds to the first free living, post-marsupial stage. The number of eggs, embryos or juveniles carried by an incubating female varies greatly between the isopod species.

The aim of this paper is to report on biological aspects of incubating females of Janaira gracilis Moreira \& Pires, especifically to those related to the marsupium and their brood.

\section{MATERIAL AND METHODS}

Janaira gracilis is extremely abundant among the sublittoral brown seaweed Sargassum cymosum C. Agardh, which grows 1uxuriantly on rocks lying along the side of the pier of the Base Norte $\left(23^{\circ} 30^{\prime} \mathrm{S}, 45^{\circ} 07^{\prime} \mathrm{W}\right)$, Instituto Oceanográfico, University of São Paulo, north littoral of State of São Paulo, Brazil.

The Sargassion cymosum samples were collected monthly, from January 1972 though January 1973, and washed free of animals in the laboratory. All animals from the washed samples were then transferred to $70^{\circ}$ alcohol, and later a11 isopod specimens, including the Janaira gracilis incubating females, were picked out under a low power binocular microscope.

The specimens were measured from above in extended condition, and kept flattened, when needed, by a light pressure from a needle. The measurements were taken from the midanterior margin of the head to the apex of the pleotelson. The examined eggs, embryos and juveniles were extracted from the marsupium, staged according to their development, counted and measured. The post-marsupial stages referred to in the text were classified following Zimmer's (1926) terminology, as applied by Hessler (1970).

The temperature of the water was recorded every month at the time of the collection. Water samples for measurement of the salinity (determined by the Knudsen method) and dissolved oxygen (measured by the Winkler method) were collected at the same time.

The water temperature varied from $22.0^{\circ}$ to $28.5^{\circ} \mathrm{C}$. Higher temperatures (average $27.3^{\circ} \mathrm{C}$ ) were found between December-April (warm season), being low- 
er (mean $23.2^{\circ} \mathrm{C}$ ) at the remaining months. The values of the salinity varied from 31.2 to $35.4 \%$, whereas those of the oxygen content varies from 3.24 to $5.00 \mathrm{ml} / \mathrm{l}$.

\section{THE MARSUPIUM}

The Janaira gracilis external brood pouch is oblong-oval and formed by 4 pairs of laminar expansions, i.e., the oostegites, which arise from the inner bases of each of the pereopods I-IV. The oostegites overlap one another beneath the pereon forming a rather tight chamber, enclosing a space into which the eggs and later the embryos and juveniles are confined. The general shape of the marsupium is shown in Figure 1.

The oostegites appear for the first time at the female post-marsupial stage 7 of development (preparatory stage 1, mean size $1.65 \mathrm{~mm}$ ). At this stage the oostegites are minute buds (about $1 / 5$ length of basis of respective pereopods), and have the appearance of rigid, uniformly thicked expansions (Fig. 2).

After a moult, at the consecutive post-marsupial female stage 8 (preparatory stage 2, mean size $2.21 \mathrm{~mm}$ ), the oostegites have grown distinctly, reaching now to a size of about $2 / 3$ length of basis of pereopods. However, as in the preceding reproductive preparatory stage, they basically still retain both the general shape and structure (Fig. 3).

After a new moult (female post-marsupial developmental stage 9 = brooding stage 1, average size $2.22 \mathrm{~mm}$ ), the oostegites have grown considerably overlaping each other beneath the pereon, attaining in the incubating females a size of about 2.2 times the length of the respective basis. At this stage the oostegites are fully developed and form the marsupium (Fig. 1).

Each oostegite in the incubating females is thick at the basal region, but at the margins it became thin and membranous. From the base of the oostegites departure irregular, radial, thick reinforcements. 
The fully developed oostegites I to IV differ in size and shape, but their margins are smooth, and devoid of hooks or spines. The oostegites I are the smallest, grossly rectangular and are placed close to the maxillipeds (Figs 1 and 4). Oostegites II and III arise from pereopods II and III; they are distinctly rectangular, about equal in size and are the largest of all (Figs 5 and 6). The oostegites IV are almost circular (Fig. 7).
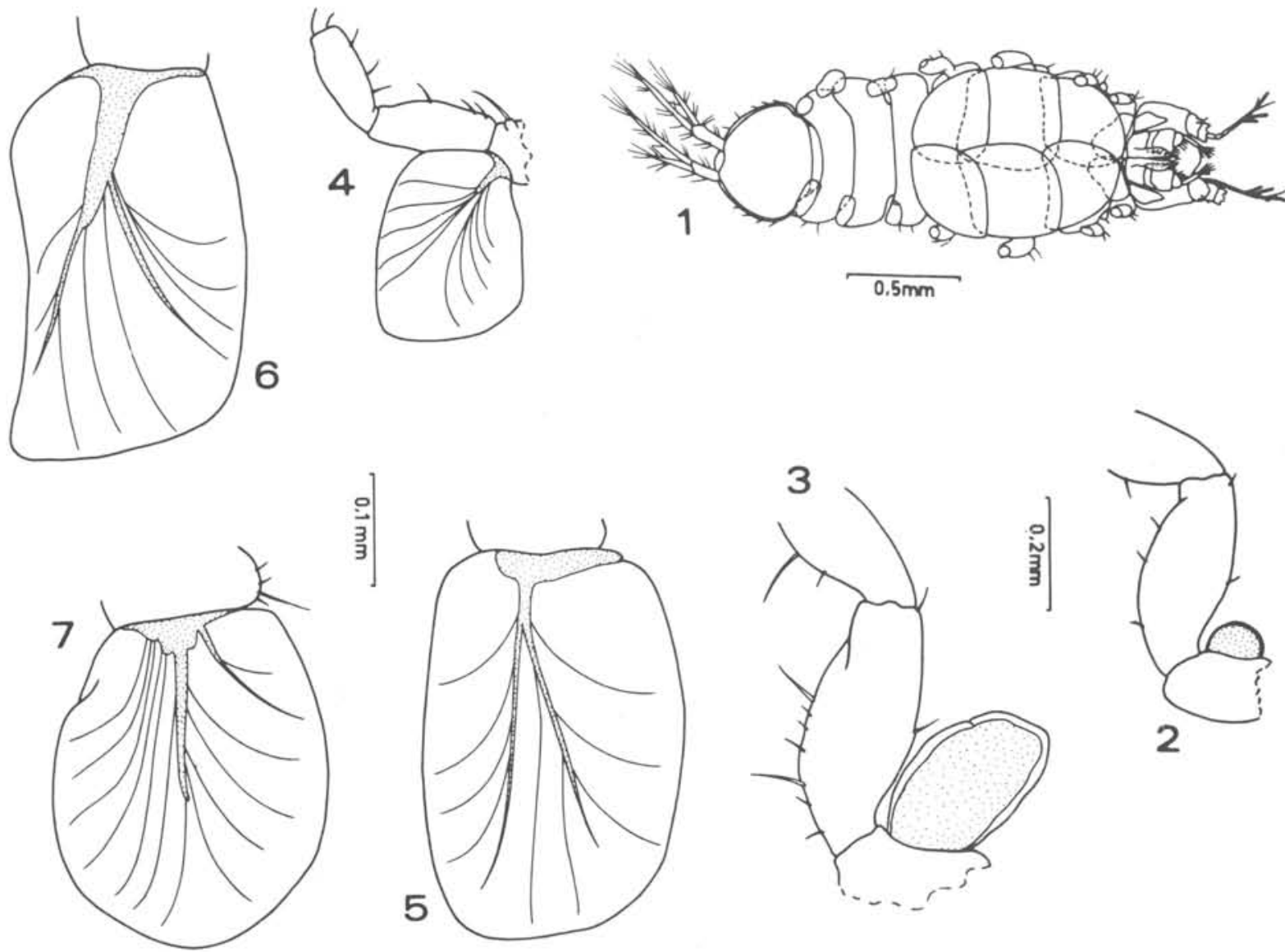

Fig. 1 - Ventral view of brooding female, post-marsupial stage 9 of development, $2.2 \mathrm{~mm}$ long.

Figs 2-3 - Outer view of left oostegite 2 of preparatory females in postmarsupial developmental stages 7 and 8 , respectively.

Figs 4-7 - Inner view of left, fully developed oostegites I to IV of brooding female in stage 9 of post-marsupial development.

Figs 2-3, and Figs 4-7, respectively, are to the same scale. 
The pattern of overlaping and the relative position of the oostegites are illustrated in Figure 1. All oostegites arising from the left pereopods I-IV overlap the right ones. Concomitantly, oostegites IV-I overlap each other successively, from back to forwards (Fig. 1). The first pair, which is placed close to the maxillipeds, makes up the anterior wall of the marsupium, and is almost entirely overlaped by the second pair of oostegites. The same does not occur with the remainder three pairs. The posterior wall of the brood pouch is made up by the overlaping of the oostegites IV.

\section{MARSUPIAL DEVELOPMENT}

Pires (1975, 1977) has described the marsupial and post-marsupial developmental stages of Janaira gracilis. She reported 4 marsupial stages, and 10 post-marsupial stages for the males and 9 for the females.

Eggs or embryos in any one marsupium are at the same stage of morphological development. Only $1 \%$ of the 270 females examined were carrying in one same marsupium embryos at different developmental stages. In these cases the eggs or embryos were always in two consecutive stages, with one stage greatly predominating over the other.

\section{SIZE OF EGGS}

The eggs in Janaira gracilis are usually spherical, and their sizes varie between 110 and $210 \mu$.

Mauchline's (1973) methodology was applied to investigate the relation between egg diameter and size of the incubating females.

A total of 84 brooding females were used to show that relationship. The calculated values mean diameters and average volumes of the eggs were plotted against the females body lengths raised to the third power (Table I). A linear regression analyses was applied to these data (Fig. 8), resulting a regression equation defined by the formula: $y=17.377+0.781 x$. The correlation coefficient $r=0.573$ is significant at the $0.1 \%$ level. 
TABLE 1 - Mean egg volumes in relation to body volume of incubating females (mean diameters analysed)

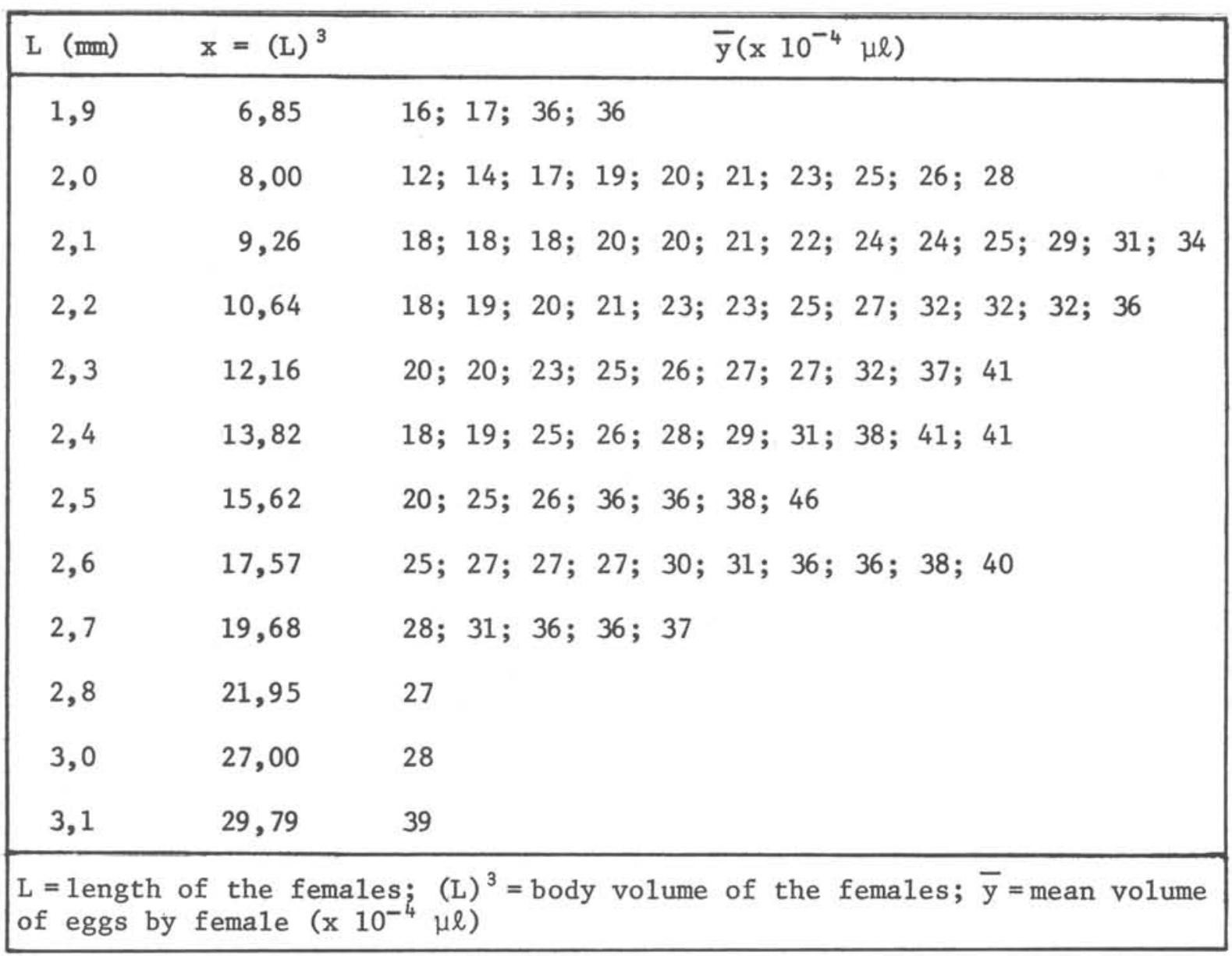

It seems clear that in Janaira gracilis there is a linear relation between volume of the eggs and volume of the females, i.e., egg size increases with the body size of the females.

On the other side, the low value of the correlation coefficient points out a great scattering of points around the regression line, indicating that small females can carry larger eggs while larger females can bear relatively sma11 eggs (Fig. 8).

\section{NUMBER OF EGGS}

The number of eggs per female varies from 9 to 56. The most commonly number found per female varies between 13 and 40 . The average number is 22 . 
The number of eggs is directly related to the size of the incubating female. Jensen $(1955,1958)$ has shown that the number of eggs in species of Malacostraca (including species of isopods) is a linear function of the body volume of the female.

Following Jensen's approach, 270 incubating females collected through one-year period were grouped in $0.1 \mathrm{~mm}$ intervals, and the average numbers of eggs per female classes were calculated (Table II). From the linear regression analyses (Fig. 9) derived a line defined by the formula: $y=4.887$ $+1.444 x$. The regression coefficient $r=0.780$ is significant at the $0.1 \%$ leve1.

TABLE 1 - Average brood numbers in relation to length of 270 incubating females (62 means analysed)

\begin{tabular}{|c|c|c|}
\hline$\overline{\mathrm{L}}(\mathrm{mm})$ & $x=(\bar{L})^{3}$ & $\bar{y}$ \\
\hline 1,95 & 7,41 & $13 ; 14 ; 15 ; 18 ; 19 ; 20,5$ \\
\hline 2,15 & 9,93 & $\begin{array}{l}13 ; 14 ; 15 ; 15,8 ; 16,5 ; 18 ; 19 ; 19,3 ; 19,8 ; 20 ; 20,5 ; \\
21 ; 21 ; 21,5 ; 22,5 ; 22,5 ; 23 ; 24 ; 26\end{array}$ \\
\hline 2,35 & 12,97 & $\begin{array}{l}15 ; 16 ; 19 ; 19 ; 20 ; 20,5 ; 21 ; 21 ; 22 ; 22 ; 23 ; 23 ; 25 \text {; } \\
27 ; 28 ; 28,5 ; 35,6\end{array}$ \\
\hline 2,55 & 16,55 & $\begin{array}{l}16 ; 21 ; 24,5 ; 25 ; 26 ; 28 ; 28 ; 28 ; 28 ; 30 ; 30,7 ; 35 \text {; } \\
36 ; 38,5\end{array}$ \\
\hline 2,75 & 20,69 & $33 ; 35 ; 36 ; 36,6 ; 39 ; 40$ \\
\hline
\end{tabular}

Therefore, in Janaira gracilis the number of eggs per female is a linear function of the body volume, i.e., it is proportional to the length of the female raised to the third power. 

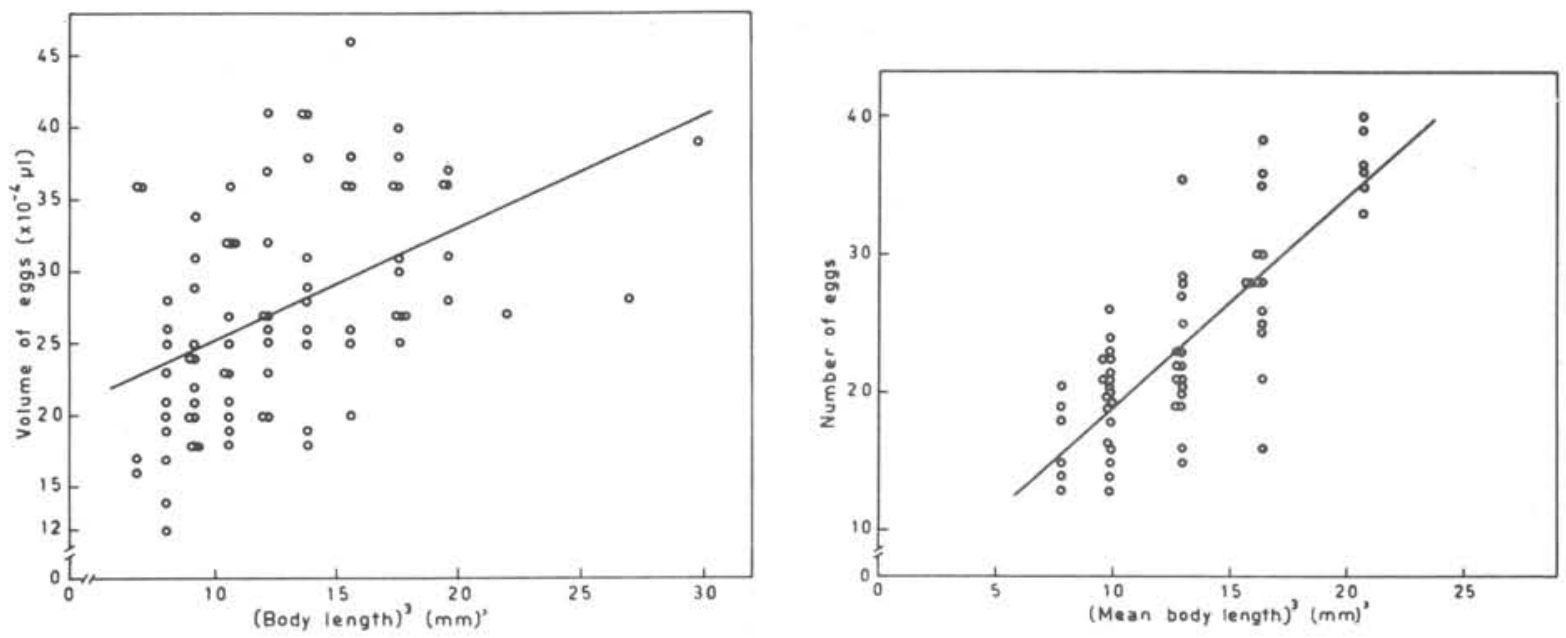

Figs 8-9 - Volume (Fig. 8) and number (Fig. 9) in the brood pouch in relation to the body volumes of incubating females. The trend line is derived by linear regression.

\section{MARSUPIAL MORTALITY}

Four morphologically distinct marsupial stages of development (Pires, 1975) were recognized in Janaira gracilis. These marsupial stages are briefly characterized as follows:

Stage A - Newly released eggs surrounded by one single egg membrane. Initially the eggs are spherical, becaming oval towards the end of the stage. Average size $150 \mu$.

Stage B - Embryos elongate, surrounded by the first embryonic membrane. Appendages buds distinct. Embryos typically comma-shaped. Average size $200 \mu$.

Stage C - Embryos enclosed by the second embryonic membrane, which covers all the appendages individually. Head, pereonal and pleonal appendages differentiated, segmented, but not functional yet. Setae absent. Mean size $330 \mu$. 
Stage D - Juveniles free, not surrounded by membrane. Body similar to adult stage but lacks the pereopods VII. The juveniles should be able of moving inside the marsupium. This stage corresponds to the first free-living post-marsupial stage. Average size $480 \mu$.

In order to investigate both the decrease in number of eggs, embryos and juveniles during the marsupial development and the average rate of brood mortality, the number of brood per female/development stage was counted, and also the average numbers and the confidence interval of the samples were determined (Table III). The statistical analyses of the difference between the average number of embryos in the consecutive stages gave the following results:

$\begin{array}{cc}\text { Comparison } & t \\ \text { Stages A/D } & 4.841 \\ \text { Stages A/C } & 1.714 \\ \text { Stages C/D } & 4.087\end{array}$

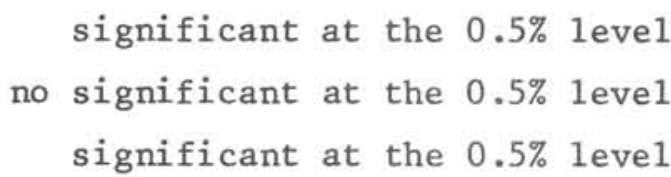

TABLE 111 - Brood numbers and range in consecutive marsupial stages in females of 2.2 and $2.3 \mathrm{~mm}$ long

\begin{tabular}{|c|c|c|c|c|c|}
\hline Stage & $\mathrm{N}$ & A & $\overline{\mathrm{x}}$ & S.D. & $I \bar{x}$ \\
\hline 1 & 27 & $9-36$ & 22,11 & 1,121 & $19,80-24,41$ \\
\hline 2 & 21 & $16-29$ & 22,09 & 0,860 & $20,30-23,88$ \\
\hline 3 & 36 & $14-32$ & 20,66 & 0,704 & $19,24-22,08$ \\
\hline 4 & 4 & $10-16$ & 13,50 & 1,320 & $9,30-17,70$ \\
\hline \multicolumn{6}{|c|}{$\begin{array}{l}N=\text { number of females analysed; } A=\text { brood range; } \\
\bar{x}=\text { mean brood; S.D. = standart deviation; } I \bar{x}= \\
\text { confidence interval at } 0.5 \text { level }\end{array}$} \\
\hline
\end{tabular}

There is no significant difference in the average number of eggs and embryos in the first three marsupial stages, but the fall in number between stages $\mathrm{C}$ and $\mathrm{D}$ is significant at the $0.5 \%$ level. Hence, the reduction in number of embryos is higher from stage $C$ to $D$, than between the preceding marsupial stages. 
The total fall in number between stages $A$ and $D$ indicates an average and overall brood mortality rate of $38.95 \%$.

\section{DISCUSSION}

There are four pairs of oostegites forming the marsupium in Janaira gracilis, as occurs in most of the known species of Asellota (Wolff, 1962). It has been reported in some bathyal and abyssal species of Asellota anomalous development of the oostegites, departing from their usual synchronic formation. Wolff (1962) has found in non-ovigerous females of Eurycope inermis and Munneurycope murrayi fully developed oostegites either only on pereopods I (E. inermis and $M$. mumayi) or only on pereopods I and IV ( $M$. murrayi).

The number of oostegites varies amongst the various subordens of isopods. The valviferans species Idotea neglecta (Kjennerud, 1952) and Idotea emarginata (Naylor, 1955) have five pairs of oostegites, as the oniscoidean Ligia oceanica (Gebelin, 1939) and the flabelliferans Eurydice pulchra and Eurydice affinis (Salvat, 1966). The flabelliferans Campecopea hirsuta (Tetart, 1962), Dynamene bidentata (Holdich, 1968), Serolis polaris, Serolis laevis, Serolis schythei and Serolis trilobitoides bear four pairs (Moreira, 1971), while the valviferan Arcturella scwayai(*) bears three pairs of oostegites (Moreira, 1973a). In species of Excirolana, mature females bear reduced oostegites which "form a genital operculum rather than a brood pouch" (Klapow, 1970, p. 359).

When first formed the oostegites are small buds, but at the incubating females they became large laminar expansions arising from the inner bases of each of the pereopods I-IV.

Holdich (1968) observed in Dynamene bidentata the first appearance of the oostegites at the female stage 7 of development (preparatory stage) but at the following stage (brooding stage), when fertilization has already occurred, the oostegites are fully developed. Thus, one moult is needed for the oostegites to reach its fully development.

(*) The correct spelling is Arcturella sawayai, not A. scavayae as in the original description of the species. 
Hessler (1970) found in Eugerda tetarta the appearance of the oostegites at stage 7 (preparatory stage 1), but at the next stage 8 the oostegites were already fully developed and forming the marsupium (brooding stage 1). In Chelator insignis the oostegites first appear at stage 5 (preparatory stage 1), reaching its fully development at stage 6 (brooding stage 1) (Hessler, op. cit.). Hence, in these two species of Asellota one single moult occurs (similarly as reported by Holdich in Dynamene bidentata) between the first appearance of the oostegites and its fully development.

It seems that in females of species of the families Haploniscidae, Munnidae and Macrostylidae the oostegites, at its first appearance, are already fully developed and forming the marsupium (Wolff, 1962). Thus, in species of these families there is no preparatory stage (in the sense of preparatory stage adopted here), but the females "progress directly from the stage without oostegites to the incubatory stage" (Wolff, 1962, p. 215). A general discussion on the subject involving other species of Asellota is provided by Wolff (op. cit.).

It seems that Janaira gracilis differs in this respect from all just reported examples. In Janaira gracilis the oostegites, once formed, grow in the subsequent moults until they reach fully development. The oostegites first appear at the female post-marsupial stage 7 (preparatiry stage 1), being fully developed only at stage 9 (brooding stage 1). Thus, two moults seem necessary for the oostegites to be fully grown since its first appearance.

Usually, most of the females die after the first brooding, as reported in Idotea neglecta (Kjennerud, 1952), Idotea emarginata (Naylor, 1955), Glyptonotus antarcticus (White, 1970), Jaera albifrons (Jones \& Naylor, 1971), Dynamene bidentata (Naylor \& Quénisset, 1964; Holdich, 1968), Jaera nordmanni nordica (Jones, 1974), Sphaeroma hookeri (Jensen, 1955) and Arcturella sawayai (Moreira, 1973b).

However, a certain number of females may survive from the first breeding, and after a moult became again reproductively mature. Hessler (1970) reports three brooding stages in Eugerda tetarta and Chelator insignis. Jensen (1955) observed in Sphaeroma hookeri kept in aquaria conditions, 
females being able to produce three broods during their life span. In Eugerda tetarta and Chelator insignis there is between each brooding stage a preparatory stage where the oostegites are reduced to rudimentary condition (Hessler, 1970). However, in Dynamene bidentata the oostegites once developed remain until death of the females (Holdich, 1968). In Janaira gracilis most of the females die after the first breeding (stage 9), but a few ones may reach stage 10 (brooding stage 2) (Pires, 1975).

The oostegites from one same marsupium varie in size and shape, as reported in Lirceus fontinalis (= Mancasellus macroums) by Markus (1930, p. 230), in Idotea neglecta (Kjennerud, 1952, figs 1-5, p. 26, 27), in Dynamene bidentata (Holdich, 1968, fig. 8, p. 146, 148) and in Arcturella sawayai by Moreira (1973a, p. 193, figs 1, 7).

The pattern of overlaping of the oostegites is similar in both Janaira gracilis (Fig. 1) and Dynamene bidentata (Holdich, 1968, fig. 8). The oostegites arising from the left pereopods overlap the right ones, at the same time that the oostegites IV-I overlap each other from back to forwards.

In $1 \%$ of the incubating Janaira gracilis the eggs or embryos in any one marsupium are at the same stage of morphological development, as occurs in Idotea emarginata (Naylor, 1955), Eurydice pulchra (Fish, 1970) and Evrydice affinis (Jones, 1970), Jaera albifrons (Jones \& Naylor, 1971), Serolis completa (Moreira, 1973c), Jaera nordmanni nordica (Jones, 1974) and Serolis polaris (Moreira, 1974). In isopods it seems a general rule the uniformity of brood (Green, 1965).

However, many exceptions have been reported. Non-synchronic development of eggs or embryos in one same marsupium occurs in Idotea vixidis (Howes, 1939), Idotea neglecta (Kjennerud, 1952) and in Limnomia tripunctata and L. quadripunctata (E1tringham \& Hockley, 1961). Holdich (1968) recorded in Dynamene bidentata that only in approximately $75 \%$ of the incubating females the embryos are at the same stage of development.

There is a linear relation between volume of eggs and volume of the females, i.e., egg size increases with body size of the females. In relation to the size, the range in number of eggs is more conspicuous than the range in diameter. The data show that small Janaira gracilis females can bear 
larger eggs while larger females can carry relatively small eggs. However, there is undoubtedly a trend for larger females to bear more and larger eggs in the brood pouch than the smaller ones.

The total number of eggs and embryos produced by individual females of a free living marine isopod species is highly variable. It may ranges 1 to 8 in Nannoniscus analis (Wolff, 1962), and from 356 to 1,020 in Glyptonotus antarcticus (Dearborn, 1967).

In Janaira gracilis the number of eggs and embryos per female ranges from 9 to 56, average 22, while in Sphaeroma hookeri it ranges from 31 to 158, mean 55 (Jensen, 1955), in Jaera albifrons from 11 to 45, mean 25 (Wolff, 1962) and in Dynamene bidentata from 25 to 137 , average 57-90 (Holdich, 1968).

As expected, the number of eggs usually varies greatly per female length class. In Janaira gracilis, females with a body length of $1.95 \mathrm{~mm}$ may bear from 13 to 20 eggs, while those of $2.75 \mathrm{~mm}$ may bear from 33 to 40 eggs. Females of Jaera albifrons of the length class 3.5 mm may bear from about 3 to 40 eggs (Jones \& Naylor, 1971).

The number of eggs and embryos in the marsupium has usually been related to the length (Bourdon, 1964; Talin, 1970; Klapow, 1970; Jones \& Naylor, 1971; Jones, 1974) or to the surface area of the ovigerous female (Holdich, 1968). However, this number is better expressed in relation to the body volume of the incubating female, i.e., to their length raised to the third power (Jensen, 1955, 1958). As a general rule, there is a linear relationship between the length, surface area or volume of the brooding female and the number of eggs and embryos in the marsupium, i.e., larger females tend to bear a higher number of eggs/embryos.

It was pointed out by Menzies (1954) that other factors than size if incubating females should be considered in the analyses of brood numbers, since the production of eggs may be related to the ecology and behavior, which influence the survival rate.

Parasitic species, whose young spend part of their life cycle in the plankton, has higher fecundity than species that live in burrows, as Limnoria, which have a high survival rate and produce few eggs (Holdich, 1968). 
Limnoria lignomum produce an average of 10-12 more eggs in the summer, when the incubating females are smaller, than in the winter (S $\phi$ mme, 1941). Saudray \& Lemercier (1960) remarked that larger females not necessarily produce the highest number of eggs, and that the fecundity should be related to other factors as age of the breeding females, heredity andenvironmental conditions. It should also be remarked that the number of eggs may be related to the rate and constancy of egg production.

Janaira gracilis, living mostly among the sublitoral alga Sargassum cymosum, which undoubtedly offers to the species a high degree of protection, is well adapted to its habitat, where it greatly out numbers (about 50 times) the other co-occurring species of isopods. Moreover, it reproduce continuously throughout the year (Pires, 1975). Therefore, it seems valid to relate the low fecundity and the high survival rate exhibited by Janaira gracilis, besides genetic controling factors, to its reproductive and behavioral adaptations to their habitat and environmental conditions.

There is a reduction in brood number, due to mortality, as marsupial development proceeds from stage 1 to stage 4.

The overall mean percentage brood mortality in Janaira gracilis is $38.95 \%$, which is higher than in Asellus intermedius (17.0\%, E11is, 1961), Dynamene bidentata (36.4\%, Holdich, 1968) and Jaera nordmanni nordica (26.5\%, Jones, 1974), but lower than in Jaera albifrons, J. ischiosetosa, $J$. praehirsuta and $J$. forsmani (about $50.0 \%$, Jones \& Naylor, 1971). However, in other species of isopods, as in Idotea neglecta (Kjennerud, 1952), Idotea emarginata (Naylor, 1955) and Ligia pallasii (Carefoot, 1973) there is no reduction in number of eggs and embryos during the period of incubation.

Several explanations are provided for the decline in number of eggs and embryos during the marsupial development. Hatchett (1947) believed it to be due, in the oniscoidean Cylisticus convexus, to the failure of the eggs to develop. In Asellus aquaticus and Idotea viridis it is explained as possibly due to lack of space into the marsupium for the development of the embryos (Jancke, 1924, 1926). Due to the size increase of the brood as the marsupial development proceeds, many eggs and embryos would be expelled. The decrease in number in Asellus aquaticus might be due (Stee1, 1961) to: 1. the parents 
eat the eggs; 2. canibalism among the embryos into the marsupium and 3. death of eggs. Klapow (1970, p. 364) estimated cnly indirectly the brood mortality (about 19.0\%) in Excirolana chiltoni because direct measurements "could not be made since defective embryos are reabsorved leaving only scanty remains". It seems that further data should be secured envisaging the understanding of the causes of the reduction of the brood number. Many other informations, as for instance, how long one given stage lasts longer than other, should also be obtained for a truly understanding of the significance or relevence of the loss of brood.

In spite of the overall decrease in the average number of brood, in $\mathrm{Ja}$ naira gracilis such reduction is significant only between the last marsupial stages (i.e., between stages $\mathrm{C}$ and D), as reported also for Dynamene bidentata (Holdich, 1968) and Jaera nordmanni nordica (Jones, 1974). Considering that in the last marsupial stage the young are capable of locomotion (Kjennerud, 1952; Jones, 1974), the reduction in number could be due to the premature released of the young.

Lemercier (1957) in Jaera marina, and Saudray \& Lemercier(1960) in Ligia oceanica, reported that eggs or embryos prematurely liberated from the marsupium are able to survive and to develop normally.

A premature release of eggs or embryos may be of great significance to a species, since by this way a number of specimens could be able to survive, in spite the absence of marsupial protection. This significance still increases since the incubating females are in any way free from predators, independently of how efficient are their defensive patterns and how greater the protection provided by the habitat.

RESUMO

São descritos, no presente trabalho, vários aspectos relacionados à biologia de fêmeas grávidas de Janaira gracilis Moreira \& Pires. 0 marsúpio é formado por 4 pares de oostégitos, que partem dos pereópodos I-IV. 
Os oostégitos, que surgem pela primeira vez no estádio 7 do desenvolvimento pós-marsupial (estāgio preparatório 1), crescem nas sucessivas mudas, atingindo no estágio 9 (estágio reprodutor 1) seu pleno desenvolvimento. 0 tamanho dos ovos é proporcional ao tamanho das fêmeas. 0 número de ovos, por fêmeas, é proporcional ao volume das fêmeas, isto é, a fecundidade é mais elevada nos exemplares de maior comprimento. 0 número de ovos, embriões e jovens decresce com o desenvolvimento marsupial, sendo este decréscimo maior entre os dois últimos estágios marsupiais (i.ē., entre os estágios C e D) do que entre os estágios precedentes. A taxa média de mortalidade marsupial é de $38.95 \%$.

\section{REFERENCES}

BOURDON, R. 1964. Notes sur la biologie de Dynamene bidentata Adams (Isopode, Sphaeromatidae). Bull. trimest. Acad. Soc. Lorraines Sci., $4: 155-162$.

CAREFOOT, T. H. 1973. Studies on the growth, reproduction and life cycle of the supralittoral isopod Ligia pallasii. Mar. Biol., 18(4): 302-311.

DEARBORN, J. H. 1967. Food and reproduction of Glyptonotus antarcticus (Crustacea: Isopoda) at McMurdo Sound, Antarctica. Trans. Roy Soc. New Ze1., zoo1., 8(15):163-168.

ELLIS, R. J. 1961. A life history study of Asellus intermedius Forbes. Trans. Am. microsc. Soc., 80(1):80-102.

ELTRINGHAM, S. K. \& HOCKLEY, A. R. 1961. Migration and reproduction of the wood-boring isopod, Limnoria, in Southampton water. Limnol. \& Oceanogr., 6(4):467-482.

FISH, S. 1970. The biology of Eurydice pulchra (Crustacea: Isopoda). J. mar. biol. Ass. U. K., 50:753-768.

GEBELIN, F. 1939. Observations relatives a la sexualité de 1'isopode oniscoide Ligia oceanica. Développement des oostegites. Bull. Soc. zool. Fr., 64:190-200.

GREEN, J. 1965. Chemical embriology of the Crustacea. Biol. Rev., $40(4): 580-600$.

HATCHETT, S. P. 1947. Biology of the Isopoda of Michigan. Ecol. Monogr., 17:47-79. 
HESSLER, R. R. 1970. The Desmosomatidae (Isopoda, Asellota) of Gay Head-Bermuda Transect. Bull. Scripps Instn Oceanogr., 15:1-185.

HOLDICH, D. M. 1968. Reproduction, growth and bionomics of Dynamene bidentata (Crustacea, Isopoda). J. Zool., 156:137-153.

HOWES, N. H. 1939. Observations on the biology and post-embryonic development of Idotea viridis (Slabber) (Isopoda, Valvifera) from New England Creek, South-east Essex. J. mar. biol. Ass. U. K., 23:279-310.

JANCKE, 0. 1924. Die Brutpflege einiger Malakostraken. Zool. Anz., $58(9 / 10): 273-278$. Hydrobio1., 17:678-698.

Über die Brutpflege einiger Malakostraken. Arch.

JONES, D. A. 1970. Populations densities and breeding in Eurydice pulchra and Eurydice affinis in Britain. J. mar. biol. Ass. U. K., $50: 635-655$.

JONES, M. B. 1974. Breeding biology and seasonal population changes of Jaera nordmanni nordica Lemercier (Isopoda, Asellota). J. mar. biol. Ass. U. K., 54:727-736.

\& NAYLOR, E

1971.

Breeding and bionomics of the British members of the Jaera albifrons group of species (Isopoda: Asellota). J. Zool. London, $165(2): 183-199$.

JENSEN, J.P. 1955. Biological observations on the isopod Sphaeroma hookem Leach. Vidensk. Medd. dansk naturh. Foren., 117:305-339.

1958. The relation between body size and number of eggs in marine Malacostrakes. Meddr Danm. Fisk. og Havunders., n. s., 2(19): 3-28.

KJENNERUD, J. 1952. Ecological observations on Idotea neglecta G. 0. Sars. Univ. Bergen Arb. (Naturv. rekke), 7:1-47.

KLAPOW, L. A. 1970. Ovoviviparity in the genus Excirotana (Crustacea: Isopoda). J. Zoo1. London, 162(3):359-369, p1. 1.

LEMERCIER, A. 1957. Sur le développement in vitro des embryons d'un Crustacé Isopode Asellote: Jaera mamina (Fabr.). C. R. Acad. Sci. Paris, $244(9): 1280-1283$.

MARKUS, H. C. 1930. Studies on the morphology and life history of the isopod, Mancasellus macroumus. Trans. Amer. microsc. Soc., 49(3):220236, p1. 26 .

MAUCHLINE, J. 1973. The broods of British Mysidacea (Crustacea). J. mar. biol. Ass. U. K., 53(4):801-817. 
MENZIES, R. J. 1954. The comparative biology of reproduction in the wood-boring isopod crustacean Limnoria. Bull. Mus . comp. Zool. Harv., $112(5): 263-388$.

MOREIRA, P.S. 1971. Fisioecologia de isópodes do gênero Serolis Leach, 1818 (Crustacea, Serolidae). Livre Docência thesis. University of São Paulo, 297 p. + atlas.

1973a. Arcturella scavayae, a new species of Isopoda Crustacea from southern Brazil. Bolm Zool. Biol. mar., n. s., (30):185194, p1s. 1-3.

1973b. Behavioral aspects of Arcturella scawayae Moreira, 1973 (Crustacea, Isopoda, Valvifera). Bolm Zool. Biol. mar. n.s., (30): 217-232.

1973c. Biologia de Serolis completa (Crustacea, Isopoda, Flabellifera).I. Estádios de desenvolvimento. Bolm Inst.oceanogr., S Paulo, 22:93-108.

1974. New records and a new species of Serolis (Crustacea, Isopoda, Flabellifera) from southern Brazil. Bolm Inst. oceanogr., S Paulo, 23:121-153.

\& PIRES, A.M.S. Janaira gracilis, a new genus and species of Janirid isopod (Crustacea, Peracarida) from Brazil. Crustaceana (in press).

NAYLOR, E. 1955. The life cycle of the isopod Idotea emarginata (Fabricius). J. Anim. Eco1., 24(2):270-281.

\& QUENISSET, D. 1964. The habitat and life history of Naesa bidentata (Adams). Crustaceana, ?(5):212-216.

PIRES, A. M. S. 1975. Sobre a biologia de Janaira gracilis (Crustacea, Isopoda, Asellota) da fauna vágil de Sargassum cymosum. MS dissertation, University of São Paulo, 51 p., 10 tabs, 81 figs. (unpublished).

1977. Desenvolvimento marsupial e pós-marsupial de Janaira gracilis (Crustacea, Isopoda, Asellota). Bolm Inst. oceanogr., S Paulo, 26:21-50.

SALVAT, B. 1966. Eurydice pulchra (Leach, 1815), E. affinis (Hansen, 1905) (Isopodes, Cirolanidae), taxonomie, ethologie, ecologie, repartition vertical et cycle reproducteur. Act. Soc. Linn. Bordeaux, ser. A, $103: 1-77$.

SAUDRAY, Y. \& LEMERCIER, A. 1960. Observations sur le développment des oeufs de Ligia oceanica Fabr. Crustacé Isopode Oniscoide. Bull. Inst. océanogr. Monaco, (1162):1-11.

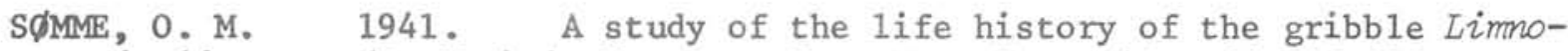
ria lignorum (Rathke) in Norway. Nytt Mag. Naturvid., 81:145-205. 
STEEL, E. A. 1961. Some observations on the life history of Asellus aquaticus (L.) and Asellus meridianus Racovitza (Crustacea: Isopoda). Proc. zool. Soc. Lond., 137(1):71-87.

TALIN, J. 1970. Sur le cycle biologique de Sphaeroma hookeri Leach (Isopode flabellifère) dans les eaux de la Durançole (B. du Rh.) Hydrobiologie, $36(2): 295-303$.

TETART, J. 1962. Etude morphologique de Campecopea hirsuta (Montagu). Bul1. Soc. Linn. Normandie, 10(3):158-164.

WHITE, M. G. 1970. Aspects of the breeding biology of Glyptonotus antarcticus (Eights) (Crustacea, Isopoda) at Signy Island, South Orkney Islands. In: Holdgate, M. W., ed.- Antarctic ecology. London, Academic Press, vo1. 1:279-285.

WOLFF, T. 1962. The systematics and biology of bathyal and abyssal Isopoda Asellota. Galathea Rep., (6):1-320, p1s. 1-19.

ZIMMER, C. 1926. Northern and Arctic invertebrates in the collection of the Swedish State Museum. X. Cumaceen. K. svensk VetenskAkad. Handl., ser. $3,3(2): 1-88$.

(Received August 22/1975) 